Journal of Physics and Its Applications

Journal homepage: https://ejournal2.undip.ac.id/index.php/ipa/index

\title{
Identification of Landslide with Resistivity Method at Candi Industrial Area, Ngaliyan, Semarang
}

\author{
Nuriyana Muthia Sani, Agus Setyawan, Rahmat Gernowo \\ Department of Physics, Faculty of Science and Mathematics, Diponegoro University, Semarang, Indonesia \\ *Corresponding author:nuriyanamuthia@gmail.com
}

\section{A R T I C L E I N F 0}

\section{Article history:}

Received: 24 March 2021

Accepted: 30 April 2021

Available online: 28 May 2021

\section{Keywords:}

Landslide

Electric resistivity

Candi Industrial Area

\begin{abstract}
A B S T R A C T
Landslides can be occurred in almost every natural slope or artificial slope slowly or suddenly with or without any prior signs. The main reason for slope collapse is the increase in shear stress in the landslide, the decrease in shear strength, or both. Landslide problems can result in loss of life and property, damage to the environment, infrastructure, public facilities, and disrupt livelihood generally. Landslides can be detected by exploration of the subsurface. The geoelectrical method is one of the geophysical methods to know the change of resistance of a type of rock layer below ground level. The research aims to interpret the lithology of the subsurface in the Candi Industrial Area, Ngaliyan, Semarang using Schlumberger configuration. The results of measurements are voltage and electric current to calculate the apparent resistivity value processed by IP2Win software to determine the lithology and the slip surface area. The results present that lithology in the research area consists of sand clay, clay, and sandstone. The results showed that the locations of landslide-prone areas lie at the contact between sand clay and clay with that area at a depth of between $19.95-31.62 \mathrm{~m}$ there is one difference in the resistivity value which can be assumed to be a slip surface.The result of the research can be used to make policy rules of landslide mitigation.
\end{abstract}

\section{Introduction}

Natural disasters are a part of human life that cannot be predicted. As the capital of Central Java province, Semarang has experienced rapid development marked by the implementation of development in the industry field. The development must be balanced with more specific handling of disaster control. Otherwise, natural disasters such as landslides cannot be avoided. Central Java province is the highest number of landslide disasters. As an industrial city, Semarang city is included in the cities and districts that have suffered landslides [1].

Landslides can be interpreted as a form of erosion that transport of land occurred in a relatively short time in a very large number. Landslide is a phenomenon as the mass movement of soil, rock, or both often occur on natural or artificial slopes. A landslide is a natural event that is looking for a new balance due to a disturbance that affects a reduction in shear strength as well as an increase in soil shear stress [2]. Landslide is caused by heavy rains so that water content in the soil layer and load increases. The water will penetrate until the soil is impermeable. This layer will act as a slippery slip surface. But the lithology, slope angle, slope aspect, and slope profile are related to predisposing factors which are static and inherent to the terrain.
Research in a landslide with geoelectric resistivity has been carried out, including identificationof landslide with resistivity method Wenner-Schlumberger Configuration at Bendanduwur Semarang as the first step of landslide disaster mitigation[3]. Identify landslide areas using resistivity methods Wenner-Schlumberger configuration in Meunasah Krueng Kala Area, Aceh Besar[4]. Application of resistivity survey method in landslide investigations along Mettupalayam to Coonoor Highway, Nilgiris District, Tamilnadu, India [5].

According to the latest phenomenon, landslides in the Candi Industrial Area,Ngaliyan, Semarang are suspected due to dredging land of factory construction. Geological conditions that include the morphology of the area such as hills and slopes, as well as lithological conditions that make up the area become factors that affect landslides. To find out the existence of underground in the Candi Industrial Area it is necessary to research. The method used to determine the physical properties of the earth is the geophysical method. The geophysical method used to study landslides may produce useful information on defining the internal structure of a landslide, identifying the geometry of sliding surface, determination of groundwater effect on the landslide, 
physical properties of landslide material, and landslide mass movement [6]. The geoelectrical method is one of the geophysical methods to know the change of resistance of a type of rock layer below ground level [7].

The research used the resistivity geoelectrical method to determine the subsurface resistivity distribution by measurements on the ground surface. From these measurements, the resistivity of the subsurface can be estimated. Geoelectrical resistivity is a geophysical method that can be used in the determination of the type of rock layers that act as a sliding surface and the depth of the earth's surface [8].

The principle of this method is the measurement of the flow of electricity on the inside surface of the earth and how to detect the earth's surface. This method covers the measurement of voltage and electric current caused by the injection of an electric current into the earth through a pair of current electrodes. The voltage is measured in a pair of electrode potential. The research was used the Schlumberger configuration. Schlumberger configuration is a configuration used to determine the layers of rock in a vertical direction. The depth of the estimation has a positive correlation with the distance of the electrode range. The deeper estimation, the wider distance of the electrode. The research aims to interpret the lithology of the subsurface in the Candi Industrial Area, Ngaliyan, Semarang. Landslides usually occur in clay layerswithresistivity values $<10 \Omega \mathrm{m}[9]$.

\section{Methodology}

The data used in this research was secondary data geoelectrical resistivity in Schlumberger configuration from PT SelimutBumi Adhi Cipta, Semarang. The data took place in Candi Industrial Area, Ngaliyan, Semarang. The data consists of the voltage and the electric current injected into the earth through a pair of current electrodes.In general, the electrode configuration of Schlumbergercan be seen in Fig. 1.

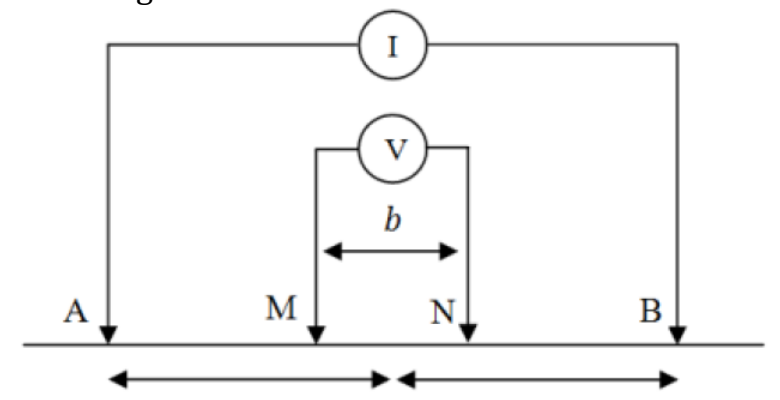

$a$

$a$

Fig 1: Schlumberger Array[10].

Figure 1 was shown an $\mathrm{A}$ is a positive current electrode, $B$ is a negative current electrode, $M$ is a positive potential electrode, and $\mathrm{N}$ is a negative potential electrode. The Schlumberger configuration has a larger electrode current than the potential electrode spacing. The apparent resistivity value can be calculated using the formula below[10]:

$$
\rho_{\alpha}=k \frac{V}{I}
$$

$k$ is the geometric factor, its size depends on the type of configuration used. Geometry factor can be calculated using the formula below[10]:

$$
k=2 \pi\left\{\left(\frac{1}{r_{1}}-\frac{1}{r_{2}}\right)-\left(\frac{1}{r_{3}}-\frac{1}{r_{4}}\right)\right\}^{-1}
$$

$r_{n}(n=1,2,3,4)$ is the distance between electrodes. $r_{1}$ is the distance between $\mathrm{A}$ and $\mathrm{M}, r_{2}$ is the distance between $\mathrm{M}$ and $\mathrm{B}, r_{3}$ is the distance between $\mathrm{A}$ and $\mathrm{N}$, and $r_{4}$ is the distance between $\mathrm{N}$ and $\mathrm{B}$. Therefore, the geometric factor of the Schlumberger array can be obtained by the formula below[10]:

$$
k=\pi \frac{a^{2}}{b}\left(1-\frac{b^{2}}{4 a^{2}}\right)
$$

The Schlumberger configuration is very reliable in determining aquifer areas and landslide areas as in researchdetermination of groundwater using Geoelectric Method: Schlumberger configuration in Rokan Hulu Regency [11], Identification of aquifer using geoelectric resistivity method of reciprocal Schlumberger array (Case Study: Tanggamus, Lampung Province) [12], groundwater analysis using vertical electrical sounding and water quality testerin Sukolilo Area, Surabaya, East Java: significant information for groundwater resources [13], Identification of aquifer potential by using Resistivity Method: a case study in Kedawung and Sambirejo District, Sragen, Central Java, Indonesia [14],Identification of basement rock on landslide zone using Geoelectric Method (Case Study of Selili Region, District of SamarindaIlir, Samarinda, East Kalimantan)[15], and Application of 2D Spatial Imaging Method for Identification of A Fault Lines and Subsurface Landslide at "Taman Unnes", Semarang, Indonesia[16].

Fig. 2 shows the administrative map of Semarang City. The research in the Ngaliyan Sub-District is in Damar Formation [2]. Damar formation is presented in Fig. 3. This method was done in 7 measuring lines.

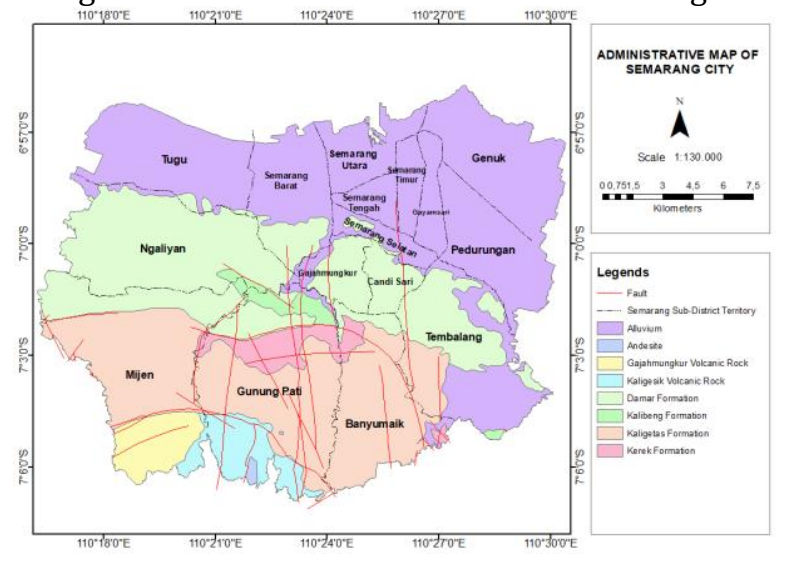

Fig 2: Administrative Map of Semarang City. 


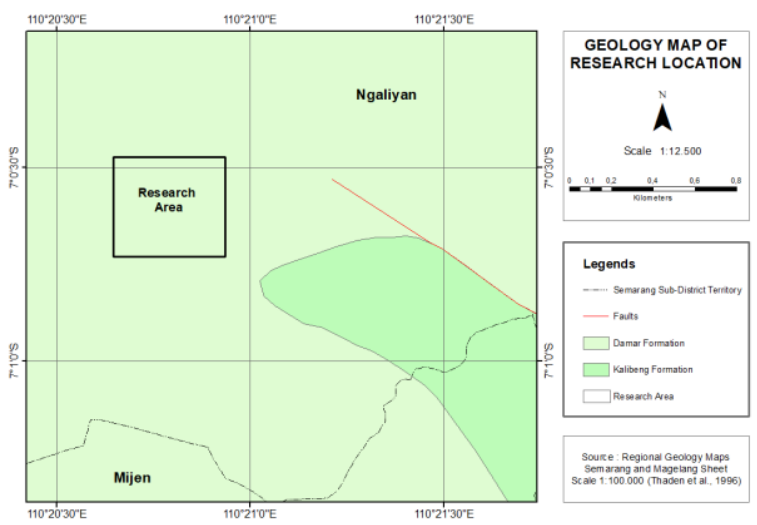

Fig 3: Geology Map of Research Area.

\section{Geoelectrical ResistivityMethod}

Geoelectrical resistivity measurement data was computed by IP2Win software with Schlumberger configuration and resulted in an image. The specific resistance value of each rock stratum and its depth in the ground also could be analyzed from IP2Win software.There is the $7^{\text {th }}$ line of geoelectric data. The first and second lines are $40 \mathrm{~m}$ in length. In the third, until seven-line is $50 \mathrm{~m}$ length. After data processing, interpretation data performed by correlating the data processing with basic knowledge aspect apparent resistivity and geological condition of the research area.

\section{Results and Discussions}

Based on the regional geology mapping of Semarang, the research area is located in Damar formation. It contains clay, sandstone, tuff, and breccia [17]. Figures 3 to 9 illustrate the result of rock type resistance value with mapping model on line 1 to line 7 is created using IP2Win software. Data validation is carried out by matching borehole logging and geological information.

\section{First Line}

The first line, the matching curve, and the resistivity table are shown in Fig. 4.

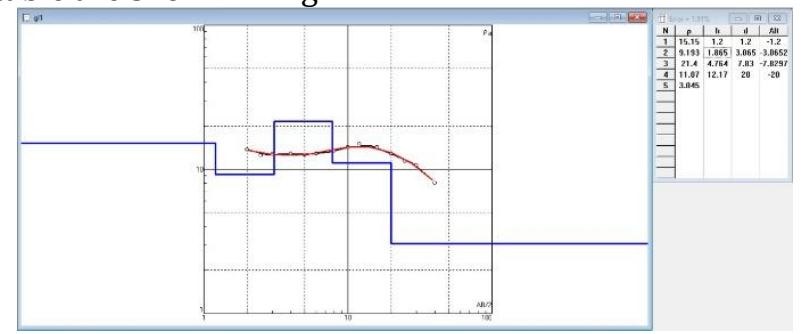

Fig 4: Matching Curve and Resistivity Table in Line 1.

The result of the first line interpretation is consists of four layers of rock. The first layer has a resistivity value of $15.15 \Omega \mathrm{m}$ with a depth of $0-1.2$ $\mathrm{m}$ is a topsoil layer in the form of sand clay. The second layer has a resistivity value of $9.193 \Omega \mathrm{m}$ with a depth of $1.2-3.065 \mathrm{~m}$ is interpreted as sand clay. The third layer has a resistivity value of $21.4 \Omega \mathrm{m}$ with a depth of $3.065-7.83 \mathrm{~m}$ is interpreted as clay. The fourth layer has a resistivity value of $11.07 \Omega \mathrm{m}$ with depth $7.83-20 \mathrm{~m}$ is suspected to be a layer of sandstone.

\section{Second Line}

Figure 5 shows the result of the matching curve and resistivity table in second-line interpretation is consists of two layers of rock.

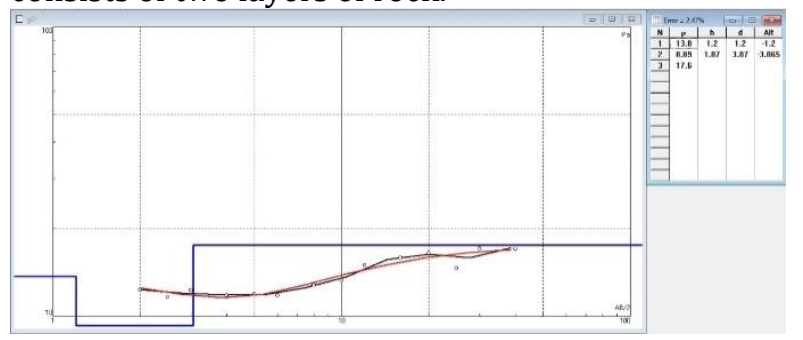

Fig 5: Matching Curve and Resistivity Table in Line 2.

The first layer in the second line has a resistivity value of $13.8 \Omega \mathrm{m}$ with a depth of $0-1.2 \mathrm{~m}$ is a topsoil layer in the form of sand clay. The second layer has a resistivity value of $8.89 \Omega \mathrm{m}$ with a depth of $1.2-3.07$ $\mathrm{m}$ is interpreted as sand clay.

\section{Third Line}

The third line, the matching curve, and the resistivity table are shown in Fig. 6.

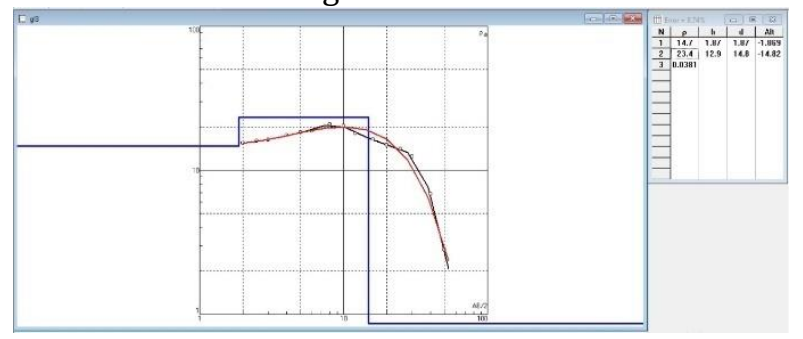

Fig 6: Matching Curve and Resistivity Table in Line 3.

The first layer in the third line has a resistivity value of $14.7 \Omega \mathrm{m}$ with a depth of $0-1.87 \mathrm{~m}$ is a topsoil layer in the form of sand clay. The second layer has a resistivity value of $23.4 \Omega \mathrm{m}$ with a depth of $1.87-14.8 \mathrm{~m}$ is interpreted as sandstone.

\section{Fourth Line}

In the fourth line, the matching curve and resistivity table is shown in Fig. 7.

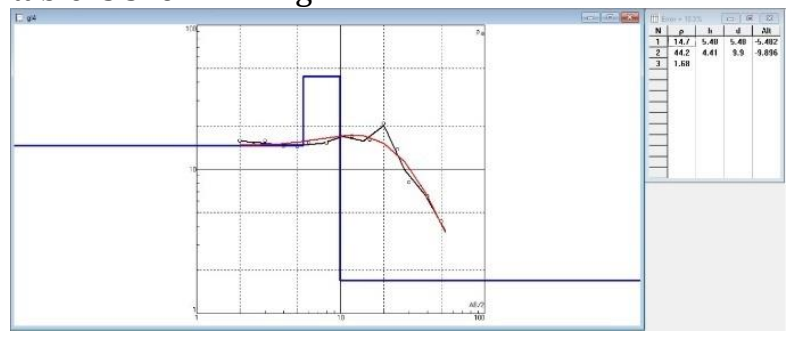

Fig 7: The Matching Curve and Resistivity Table in Line 4.

The first layer in the fourth line has a resistivity value of $14.7 \Omega \mathrm{m}$ with a depth of $0-5.48 \mathrm{~m}$ is a topsoil layer in the form of clay. The second layer has a resistivity value of $44.2 \Omega \mathrm{m}$ with a depth of $5.45-$ $9.9 \mathrm{~m}$ is interpreted as clay. 


\section{FifthLine}

The fifth line, the matching curve, and the resistivity table are shown in Fig. 8.

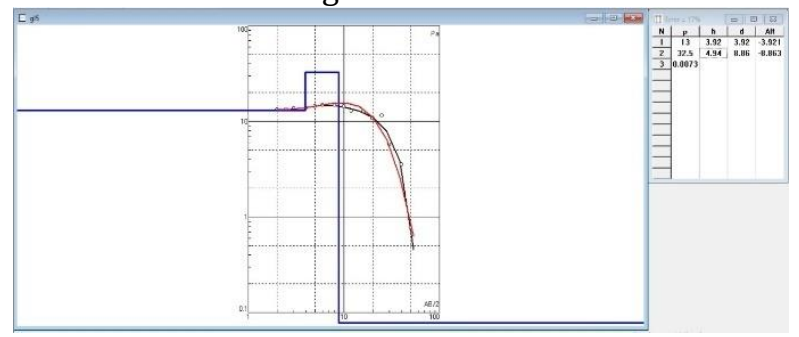

Fig 8: The Matching Curve and Resistivity Table in Line 5.

The first layer in the fifth line has a resistivity value of $13 \Omega \mathrm{m}$ with a depth of $0-3.92 \mathrm{~m}$ is a topsoil layer in the form of sand clay. The second layer has a resistivity value of $32.5 \Omega \mathrm{m}$ with a depth of 3.92 $8.86 \mathrm{~m}$ is interpreted as clay.

\section{Sixth Line}

Figure 9 shows the result of the matching curve and resistivity table in sixth line interpretation is consists of two layers of rock.

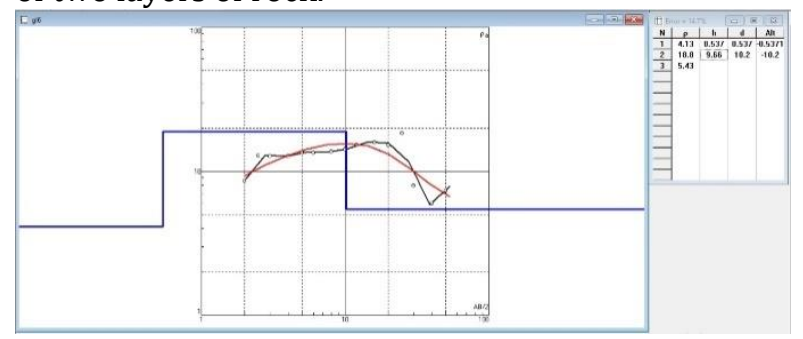

Fig 9: The Matching Curve and Resistivity Table in Line 6.

The first layer in the sixth line has a resistivity value of $4.13 \Omega \mathrm{m}$ with a depth of $0-0.537 \mathrm{~m}$ is a topsoil layer in the form of sand clay. The second layer has a resistivity value of $18.8 \Omega \mathrm{m}$ with a depth of $0.537-10.2 \mathrm{~m}$ is interpreted as clay.

\section{Seventh Line}

In the seventh line, the matching curve and resistivity table are shown in Fig. 10.

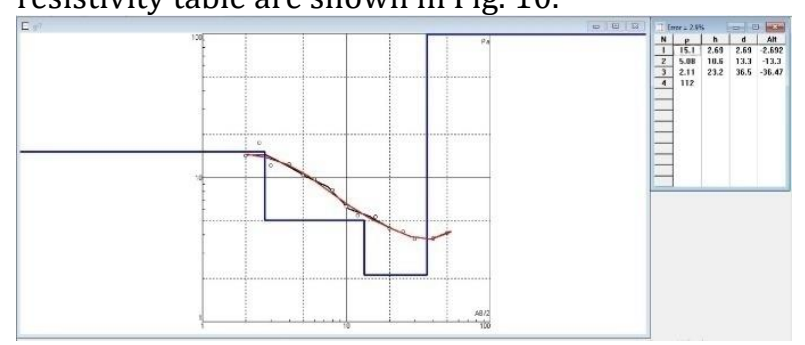

Fig 10: The Matching Curve and Resistivity Table in Line 7.

The first layer in the seventh line has a resistivity value of $15.1 \Omega \mathrm{m}$ with a depth of $0-2.69 \mathrm{~m}$ is a topsoil layer in the form of sand clay. The second layer has a resistivity value of $5.08 \Omega \mathrm{m}$ with a depth of $2.69-13.3 \mathrm{~m}$ is interpreted as sandstone. And the third layer has a resistivity value of $2.11 \Omega \mathrm{m}$ with a depth of $13.3-36.5 \mathrm{~m}$ is suspected to be a layer of sandstone.

\section{Pseudo Section}

Figure 11 shows the pseudo section of correlation between the resistivity value in line 1 to line 7 , it can be seen that the layer near the surface of $0-6.31 \mathrm{~m}$, the resistivity value is $9.62-15.3 \Omega \mathrm{m}$, indicating there is sand clay. At a depth of $6.31-39.8 \mathrm{~m}$, it is dominated by sand clay too. The boundary between the medium resistivity zone and the low resistivity zone is regarded as a slip surface [18]. It can be view at the black lines with a depth of $19.95-31.62 \mathrm{~m}$. There is a difference in the resistivity value which can be assumed to be a slip surface.However, on line 7 there is clay up to a depth of $39.8 \mathrm{~m}$. The type of rock that may be a slip surface is clay [19]. Clay is a soil that easily expands and shrinks [8]. If the clay is exposed in the dry season, it will shrink so that there are cracks. Meanwhile, during the rainy season, water can enter to fill the cracks. The location of the cracks has the possibility of landslides. The more cracks in the subsurface, the greater possibility of landslides [20]. Clay is impermeable, so the water that enters was trapped cannot be escaped by the clay. The water that accumulates on the clay above the hard rock lead will harden[9]. The slippery clay formed as a field of experience weathering material above it moves. The steeper the slope, the faster the acceleration of the slip plane. Otherwise, the more gentle the slope, the slower the acceleration of the slip plane.This can lead to landslides. So, need anticipated actions to prevent landslides.

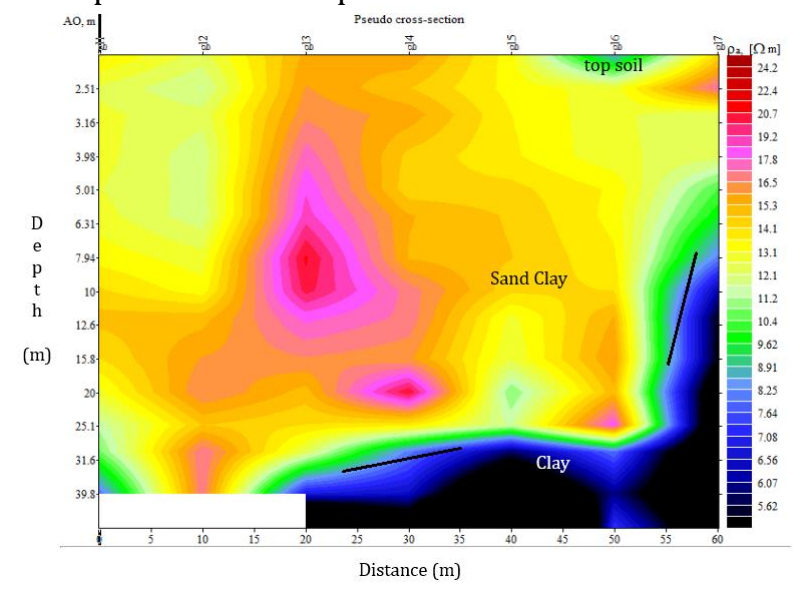

Fig 11: Pseudo Section of Resistivity Value Line 1 to Line 7.

The black lines are interpreted as a slip surface which results in landslides at any time if there was heavy rain for a long duration.The energy in the vertical plane or above the slope contains potential energy, in which case the mass moves along the slope, there is a change in potential energy (vertical plane) to kinetic energy (horizontal plane) and during a slip, there is energy lost due to friction. Therefore at a landslide location with a certain height, the mass moves over the slip plane as far as. If the topographic slope angle is greater than the slope angle, the speed will be accelerated. Otherwise, if the topographic slope angle is smaller than the slope angle, the speed will be decelerated[21].

At the research location, most of them were composed of weathered lithology, from clay to sand clay. Clays have impermeable properties which are unable to pass water, rocks with high porosity but 
unconnected pore holes. In this condition, when the clay is pressed by water, it causes the soil to become saturated and the mass on the soil increases so that the soil is unable to withstand the load and can cause landslides. In this condition, it is not strong enough if a building is built on it because the bonds of rock grains are easily brittle.

\section{Conclusions}

According to the research, the result can be obtained conclusions. The result of regional geology mapping showed that the research area contains clay, sandstone, tuff, and breccia[17]. From the result of resistivity measurement which is computed by IP2Win software, the research area contains sand clay, clay, and sandstone. The results showed that the resistivity value of $13.1 \Omega \mathrm{m}$ with depth $10-25 \mathrm{~m}$ is interpreted as sand clay. And the resistivity value of $7.08 \Omega \mathrm{m}$ with depth $7.94-39.8 \mathrm{~m}$ is interpreted as clay. The locations of landslide-prone areas lie at the contact between sand clay and clay with that area at a depth of between 19.95 - $31.62 \mathrm{~m}$ there is one difference in the resistivity value which can be assumed to be a slip surface.These results prove the content of Damar formation. From the correlation between geological and geophysical interpretation, it has a result, we assumed that the next landslide point if there is heavy rainfall, the landslide will happen in second. The result of the research can be used to make policy rules of landslide mitigation.

\section{Acknowledgment}

My biggest thanks to Allah SWT andthe research was supported by PT Selimut Bumi Adhi Cipta, Semarang, Indonesia.

\section{References}

[1] A. Rosyida, R. Nurmasari, and Suprapto, Indonesia Disaster Data 2017. Data Center, Information and Public Relation of The National Disaster Management Agency (2018).

[2] M. Chrozier, Landslides. Applied Geography, Principles and Practice. Routledge, (1999).

[3] B. T. Ramadhan et al., "Identification of landslide with Resistivity Method Wenner- Schlumberger Configuration at Bendanduwur Semarang as The First Step of Landslide Disaster Mitigation," Padjadjaran Earth D., 0-6, (2015).

[4] I. Maharani, T. A. Z. Faresi, R. S. Sari, and D. Sugiyanto, "Identification of Landslide Area Using Wenner-Schlumberger Configuration Resistivity Method in Meunasah Krueng Kala Village, Aceh Besar," J. Aceh Phys. Soc., 7, 3, 139143, (2018).

[5] R. Ganesh, B. Gowtham, T. Manivel, S. Senthilkumar, and M. Sundrarajan, "Application of Resistivity Survey Method in Landslide Investigations along Mettupalayam to Coonoor Highway, Nilgiris District, Application of Resistivity Survey Method in Landslide Investigations along Mettupalayam to Coonoor Highway, Nilgiris District," Sch. J. Eng. Tech., 9523, (2017).

[6] G. Göktürkler, Ç. Balkaya, and Z. Erhan,
"Geophysical investigation of a landslide: The Altindağ landslide site, İzmir (western Turkey)," J. Appl. Geophys.,65,2, 84-96, (2008).

[7] S. Broto and R. S. Afifah, "Geoelectric Data Processing with The Schlumberger Method," Sci. J. F. Eng., 29, 120-128, (2008).

[8] Aliyatarrafiah, A. Setyawan, and S. Widada, "Identification of The Slip Field with The Resistivity Method of Dipole-Dipole Configuration in The Bambankerep Ngaliyan Semarang," Youngster Phys. J., 3, 4, 291-298, (2014).

[9] A. Akmam, I. R. Dona, and S. D. Sari, "Optimation of Least Squares Methods Smooth Constrain Using Occam's Inversion Geoelectric Resistivity Dipole-Dipole Consfiguration for Estimation Slip Surface," in ICOMSET, 154-161, (2019).

[10] J. M. Reynolds, An Introduction to Applied and Environmental Geophysics, Second., no. 606. Chichester: JohnWiley \& Sons, Ltd, (2011).

[11] Y. Febriani, R. A. Rohman, A. Asra, M. Apriniyadi, and D. N. W. Wardani, "Determination of Groundwater Using Geoelectric Methods: Schlumberger Configuration in Rokan Hulu Regency," J. Ilm. Pendidik. Fis. Al-Biruni, 8, 2, 141-152, (2019).

[12] B. Santoso, N. Prirahmayang, and K. H. Kirana, "Identification of Aquifer Using Geoelectric Resistivity Method of Reciprocal Schlumberger Array (Case Study: Tanggamus, Lampung Province)," IOP Conf. Ser. Earth Environ. Sci., 311, 1, (2019).

[13] F. A. Bahri, H. F. Rismayanti, and D. D. Warnana, "Groundwater Analysis Using Vertical Electrical Sounding and Water Quality Tester in Sukolilo Area, Surabaya, East Java: Significant Information for Groundwater Resources," IPTEKJ. Proc. Ser., 0, 2, 74, (2017).

[14] Darsono, B. Legowo, and S. Koesuma, "Identification of Aquifer Potential by Using Resistivity Method: A Case Study in Kedawung and Sambirejo District, Sragen, Central Java, Indonesia," in ICOPIA, 776, 1, (2016).

[15] H. Lesmana and K. Subagiada, "Identification of Basement Rock On Landslide Zone Using Geoelectric Method (Case Study of Selili Region, District of Samarinda Ilir, Samarinda, East Kalimantan)," in Sch. Tech., 1, 1, (2016).

[16] L. Lashari, R. Kusumawardani, T. Cahyadi Upomo, S. Supriyadi, and A. Mugiayulhaq, "Application of 2D Spatial Imaging Method for Identification of A Fault Lines and Subsurface Landslide at 'Taman Unnes', Semarang, Indonesia," MATEC Web of Conferences, 258. 03005, (2019).

[17] R. E. Thanden, H. Sumardirdja, and P. W. Richards, Geological Map of Magelang and Semarang, Java. Bandung: Center of Geological Research and Development, (1996).

[18] R. O. Asriza, R. Supriyanto, T. H. W. Krisyanto, T. L. Indra, R. Syahputra, and A. S. Tempessy, "Determination of The Landslides Slip Surface Using Electrical Resistivity Tomography (ERT) 
Technique," in World Landslide Forum, no. December 2018, (2017).

[19] A. Akmam, H. Amir;, and A. Putra, "Optimize of Least-Square Inverse Constrain Method of Geoelectrical Resistivity Wenner-Schlumberger for Investigation Rock Structures in Malalak Districts of Agam West Sumatra," ICTVET, 5863, (2017).

[20] S. V. Ariyanto and I. Joni, "Zone Landslide
Analysis Using Geophysical Method and Analysis of Soil Type for Disaster Mitigation In Waru Pamekasan," Indones. J. Appl. Phys.,9, 2, 68-75, (2019).

[21] M. Souisa, S. M. Sapulete, and S. O. Souisa, "Estimates of Velocity and Slide Travel Distance using ELM Sliding Approach," J. Math. Appl. Sch., 13, 53-60, (2019). 